\title{
PENGARUH AUDIT TENURE, UKURAN KAP, UKURAN PERUSAHAAN KLIEN TERHADAP KUALITAS AUDIT PERUSAHAAN DI BURSA EFEK INDONESIA
}

\section{THE EFFECT OF AUDIT TENURE, KAP SIZE, CLIENT COMPANY SIZE ON AUDIT QUALITY OF COMPANY IN INDONESIA STOCK EXCHANGE}

\author{
Fitri Andriani' ${ }^{1}$, Rindi Meilani ${ }^{2}$, Chandra Evendi Pardede ${ }^{3}$, \\ Wenny Anggeresia Ginting ${ }^{4}$ \\ Universitas Prima Indonesia ${ }^{1,2,3,4}$ \\ fitriandriani3111998@gmail.com ${ }^{1}$
}

\begin{abstract}
This quantitative research aimed to explain and describe the impacts of audit tenure, KAP size and company size in industrial market in Indonesia in 2016-2018. The population included 154 companies, from which samples were randomly selected based on these following criteria is Industrial market of Indonesia 2016-2018, Incomplete financial statement 2016-2018, Unregistered names in industrial market 2016-2018. Companies conducted independent audit without explanation 2016-2018, and Financial statements were published between 2016-2018. There were 105 companies sampled in this research with 315 financial statements for 3 year-period. The data were analyzed descriptively and using logistic regression test. The results of the logistic analysis showed that Audit Tenure, KAP Size, and Company Size had a positive influence on the dependent variable of this research.
\end{abstract}

Keywords : Audit Tenure, KAP Size, Company Size, Audit Quality, Manufacturing Company, Indonesia Stock Exchange

\begin{abstract}
ABSTRAK
Penelitian kuantitatif ini bertujuan untuk menjelaskan dan mendeskripsikan dampak audit tenure, ukuran KAP dan ukuran perusahaan di pasar industri di Indonesia tahun 2016-2018. Populasi dalam penelitian ini adalah 154 perusahaan, dimana sampel dipilih secara acak berdasarkan kriteria sebagai berikut Pasar Industri Indonesia 2016-2018, Laporan Keuangan Tidak Lengkap 2016-2018, Nama Tidak Terdaftar di Pasar Industri 2016-2018. Perusahaan melakukan audit independen tanpa penjelasan tahun 2016-2018, dan Laporan keuangan diterbitkan antara tahun 2016-2018. Jumlah perusahaan yang dijadikan sampel dalam penelitian ini sebanyak 105 perusahaan dengan 315 laporan keuangan selama periode 3 tahun. Data dianalisis secara deskriptif dan menggunakan uji regresi logistik. Hasil analisis logistik menunjukkan bahwa Audit Tenure, KAP Size, dan Company Size berpengaruh positif terhadap variabel dependen penelitian ini.
\end{abstract}

Kata Kunci: Audit Tenure, Ukuran KAP, Ukuran Perusahaan, Kualitas Audit, Perusahaan Manufaktur, Bursa Efek Indonesia 


\section{PENDAHULUAN}

Seluruh perusahaan yang go public dan terdaftar dalam Bursa Efek wajib menyampaikan Laporan Keuangan yang telah diaudit oleh Kantor Akuntan Publik (KAP) sebelum dipublikasikan kepada publik. Laporan Keuangan yang telah di audit memberikan jaminan kepada pengguna laporan keuangan bahwa laporan tersebut telah layak digunakan sebagai dasar pengambilan keputusan Laporan hasil audit (audit report) bukan hanya untuk kepentingan klien, melainkan juga untuk kepentingan masyarakat, banker, analisis laporan keuangan, pemerintah, organisasi nirlaba, kreditor, dan pemegang saham yang akan membuat keputusan mengenai pinjaman dan investasinya berdasarkan laporan keuangan yang sudah diaudit oleh akuntan public. Tujuan audit atas laporan keuangan oleh auditor independen pada umumnya untuk menyatakan pendapat tentang kewajaran dalam semua hal yang material, posisi keuangan, hasil usaha, perubahan ekuitas dan arus kas sesuai dengan Standar Akuntansi Keuangan di Indonesia.

Laporan Keuangan Audit merupakan kebutuhan perusahaan dan pihak manajemen perusahaan. Laporan keuangan menjadi sangat penting karena informasi yang terkandung di dalamnya. Informasi tersebut harus memiliki kualitas yang dapat diandalkan karena dapat berguna untuk proses pengambilan keputusan. Informasi yang lebih berkualitas dapat ditingkatkan dengan memperbaiki kualitas audit (Permana, 2012). Kualitas audit memiliki sisi multidimensi dan tidak dapat diamati, maka tidak ada satu ukuran karakteristik auditor yang dapat digunakan sebagai proksi tunggal dari kualitas audit. Salah satu metode handal dengan proksi terukur adalah dengan menggunakan informasi dari laporan audit dan laporan keuangan. Untuk menilai kualitas audit dapat dilakukan adalah berbagai proksi.

Kualitas audit sebagai sebuah kemungkinan bahwa auditor akan mendeteksi dan melaporkan salah saji material. Proses pelaporan yang dilakukan oleh auditor tergantung kepada independensi auditor untuk mengungkapkan pelanggaran tersebut. Kualitas audit terdiri atas kualitas sebenarnya (actual) dan dirasakan (perceived). Actual Quality adalah tingkat dimana resiko dari pelaporan salah saji material dalam rekening keuangan berkurang, sementara Perceived Quality adalah seberapa efektif pengguna laporan keuangan percaya bahwa auditor telah mengurangi salah saji material. Perceived audit quality yang lebih tinggi dapat membantu mempromosikan investasi pada klien yang diaduit (Nugroho 2018).

Faktor lain yang dapat mempengaruhi kualitas audit adalah ukuran dari KAP dan spesialisasi auditor. Ukuran KAP dinyatakan dalam Big Four atau non Big Four, dimana semakin besar KAP dengan adanya afiliasi dengan KAP Big Four akan menghasilkan kualitas audit yang lebih baik. Karena semakin besar ukuran KAP maka tingkat independensi akan semakin tinggi pula. Begitu pula dengan spesialisasi auditor, semakin spesialis auditor maka akan semakin menguasai industri tertentu (Panjaitan, 2014). Audit fee juga mempengaruhi kualitas audit terutama dalam proses negosiasi antara manajemen dengan KAP mengenai besaran fee.

Kasus Enron dan KAP Arthur Andersen yang terungkap pada tahun 2001 menjadi perbandingan nyata terhadap hasil penelitian-penelitian yang telah dilakukan. Teori yang 
disimpulkan tentang hubungan auditor dan klien yang semakin panjang akan menghasilkan audit yang lebih berkualitas. KAP yang besar memberikan kualitas audit yang lebih baik dibandingkan KAP yang lebih kecil dan klien yang memiliki aset besar lebih mendapat jasa audit yang berkualitas karena mereka mampu membayar auditor besar kemudian menjadi sebuah pertanyaan. Namun tentu saja apa yang terjadi antara Enron dan Arthur Andersen tidak dapat mewakili pengaruh Audit Tenure, Ukuran KAP dan Ukuran perusahaan Klien terhadap kualitas audit pada perusahaan-perusahaan lain (Nugroho 2018).

Ukuran KAP bisa diukur dengan cara menghitung jumlah rekan, auditor, klien, dan pendapatan. Adapun pendapat lain oleh Permana \& Pamuji (2012) yang mengatakan bahwa ukuran KAP memiliki peranan penting dalam memutuskan hasil laporan keuangan yang diberikan kliennya Riset dilakukan bagi Panjaitan (2014) mengatakan makaKAP (Big 4) tergolong pantas KAP (Non Big 4). KAP yang tergolong lebih bertanggung jawab dalam melakukan audit dikarenakan mereka memiliki relasi yang cukup baik kepada klien sehingga apabila laporan yang disampaikan tidak memiliki keakuratan maka dapat membuat klien tersebut berkurang. Ukuran KAP dibagi tiga yaitu KAP besar yaitu KAP yang berafiliasi dengan big four, KAP medium yaitu KAP non big four namun berafiliasi dengan kantor akuntan publik asing (KAPA) atau organisasi audit asing (OAA) dan KAP kecil yaitu KAP non big four dan tidak berafiliasi dengan KAPA atau OAA.

Kualitas audit semakin meningkat dengan semakin lamanya audit tenure. Hal ini akan mendukung pendapat yang menyatakan bahwa pertimbangan auditor akan lebih baik seiring dengan masa kerja yang lebih lama karena asimetri informasi antara auditor dan klien semakin berkurang. Kualitas audit juga dapat dilihat dari lamanya audit tenure antara auditor dengan klien, tenure yang panjang dapat dianggap auditor sebagai pendapatan. Namun tenure yang panjang dapat menimbulkan adanya hubungan emosional antara auditor dengan klien, sehingga dapat menurunkan independen auditor. Oleh karena itu, diberlakukan adanya rotasi yang bersifat mandatory supaya mengurangi hubungan spesial yang terjalin antara klien dengan auditor.

Audit Tenure yang panjang juga menimbulkan rasa kekeluargaan yang lebih dan akibatnya, kualitas dan kompetensi kerja auditor dapat menurun ketika mereka mulai untuk membuat asumsi-asumsi yang tidak tepat dan bukan evaluasi yang objektif dari bukti terkini (Putri, 2014). Hubungan yang lama antara auditor dan kliennya berpotensi untuk menciptakan kedekatan antara mereka, cukup untuk menghalangi independensi auditor dan mengurangi kualitas audit.

Tenur KAP merupakan jangka waktu perikatan yang terjalin antara kantor akuntan publik dengan audit yang sama. Banyak perdebatan mengenai lama atau singkatnya tenur antara KAP atau auditor terhadap kliennya. Tenur atau masa perikatan kerja dapat berdampak pada kinerja auditor pada perusahaan kliennya seperti hubungan emosional auditor klien, independensi, fee, kompetensi.

Mengatakan bahwa Audit tenure adalah sesuatu masalahdenganmutu audit. Lamanya jalinan kerjasama dibangun oleh pengaudit dan kliennya bisa memberikan keterangan yang lengkap kepada auditor mengenai syarat-syarat yang diberikan untuk 
industry maka bisa melancarkan auditor ketika membuat pemekrisaan dan membuat laporan auditor secara independent dengan mudah (Nugrahanti, 2014). Rentang waktu yang lama yang dibangun oleh audit membuat terjalinannya hubungan yeng dekat dengan klien. Dengan hal tersebut relatif melemahkan perilaku idependesi yang dimiliki auditor dan menurunkan kualitas audit.

Hasil penelitian sebelumnya dari Panjaitan (2014), Nindita \& Siregar (2013). menyatakan audite tenure berpengaruh signifikan negatif terhadap kualitas audit. Hal ini mengindikasikan bahwa lama atau tidaknya hubungan antar klien dan auditor pada saat ini mempengaruhi kualitas audit atas dasar profesionalisme dan tanggung jawab profesi seorang auditor dalam melaksanakan tugasnya. Kedekatan yang muncul oleh karena hubungan dengan klien yang cukup panjang akan mempengaruhi integritas dan independensi auditor. Semakin panjang tenure akan semakin menurunkan kualitas audit.

Ukuran perusahaan diproksikan menerapkan log natural total asset dimiliki perusahaan sehingga perusahaan berkemampuan dalam menjaga dan meneruskan usahanya. Bertambah banyaknya aset yang perusahaan miliki, maka bertambah besar juga kekuatan perusahaan dalam menjaga usahanya."Perusahaan yang tergolong besar juga mempunyai potensi yang baik dalam melakukan pengelolaan perusahaan dan memberikan hasil laporan keuangan yang berkualitas baik. Seiring dengan ukuran perusahaan yang meningkat, kemungkinan jumlah konflik agensi juga akan meningkat dan ini mungkin akan meningkatkan permintaan untuk membedakan kualitas auditor (Sinaga 2013). Karena itu seiring dengan besarnya ukuran perusahaan maka akan digunakan pula jasa auditor besar yang memiliki profesionalitas, independensi serta kompetensi untuk menjamin pemberian kualitas audit yang lebih. Jadi dalam hal ini peningkatan kualitas audit akan tercapai mana kala auditor dapat mendeteksi kecurangan manajemen.

Laporan keuangan yang dibuat oleh pihak manajemen agar dapat dipercaya oleh para pemakai laporan keuangan, maka diperlukan pengujian oleh pihak ketiga yaitu akuntan publik atau auditor. Salah satu fungsi dari akuntan publik adalah menghasilkan informasi yang akurat dan dapat dipercaya untuk pengambilan keputusan. Tujuan audit atas laporan keuangan yang dilakukan oleh auditor yang kompeten adalah untuk menyatakan pendapat atas kewajaran, dalam hal yang meteril, posisi keuangan dan usaha serta arus kas sesuai dengan prinsip akuntansi yang berlaku umum.

Dalam melaksanakan proses audit, auditor membutuhkan pengetahuan, pengalaman, pendidikan dan pelatihan yang baik karena dengan hal itu auditor menjadi lebih mampu memahami kondisi keuangan dan laporan keuangan kliennya dan akan menghasilkan kualitas audit yang baik. Untuk menghasilkan audit yang berkualitas seorang akuntan publik yang bekerja dalam suatu tim di tuntut untuk memiliki kompetensi yang cukup. Sebagai seorang auditor kualitas audit dapt dipengaruhi oleh masa perikatan audit. KAP adalah masa jangka waktu perikatan yang terjalin antara KAP dengan auditee yang sama. Auditor bertanggung jawab untuk menyedikan informasi yang berkualitas tinggi yang akan berguna untuk pengambilan keputusan para pemakai laporan keuangan. Kualitas audit adalah kemungkinan bahwa auditor akan 
menemukan dan melaporkan pelanggaran dalam sistem akuntansi klien, temuan penganggaran tergantung pada dorongan auditor untuk mengungkapkan pelanggaran tersebut (Putri, 2014).

Auditor harus bekerja sesuai dengan standar profesional akuntan publik. Maka dari itu auditor dituntut tidak hanya dapat menjamin ada tidaknya salah saji, tetapi juga sikap profesional yang harus menjamin laporan audit yang bersih. Menurut penelitian Nugrahanti (2013) dan Sinaga \& Ghozali (2013) membuktikan variabel tenur berpengaruh positif terhadap kualitas audit, dengan kata lain semakin panjang tenur KAP, kualitas audit yang dihasilkan semakin baik. Ukuran KAP secara konsisten berpengruh positif terhadap kualitas audit. Dengan demikian dapat disimpulkan bahwa KAP besar mampu menghasilkan kualitas audit yang baik. Sedangkan ukuran KAP, auditor spesialisasi juga berpengaruh positif. Seiring dengan ukuran perusahaan yang meningkat (Sinaga, 2013).

\section{METODE PENELITIAN Populasi dan Sampel}

Populasi dalam riset merupakan area merapatkan dimana bahan atau materi yang memiliki keunggulan pula keistimewaan tersendiri yang pastila lalu ditarik kesimpulan peneliti buat dipelajari. Populasi saat riset ini yang digunakan merupakan semua industri pasar produk periode 2016-2018.

Pemilihan sampel dalam penelitian ini dilakukan dengan metode purposive sampling. Purposive Sampling merupakan teknik pemilihan sampel yang disesuaikan dengan tujuan penelitian. Kriteria sampel penelitian ini adalah Data-data mengenai variabel penelitian yang akan diteliti tersedia lengkap dalam laporan keuangan perusahaan dan Menerbitkan Laporan Tahunan (Annual Report) selama periode penelitian (2016-2018) dan menyertakan Laporan Keuangan yang telah diaudit oleh auditor independen.

Data yang sudah diapakai peneliti yaitu data sekunder rangakaian organisasi dokumentasi data penerbitan pula untuk pemakai petunjuk umum. Bukti sekunder bentuk laporan keuangan tahunan (annual report) untuk penerbitan bank. Sistem pengambilan sampel secara acak, yaitu sistem pengambilan sampel yang dilakukan dengan satuan terbaik berdasarkan kriteria utama yang ada bagi sampelnya yang tercantum, dimana penelitian ini sampel dijadikan tolak ukur perusahaan.

Tabel 1. Kriteria Penilaian

\begin{tabular}{|c|c|c|}
\hline No & Keterangan & Jumlah \\
\hline 1 & $\begin{array}{l}\text { Perusahaan Manufaktur } \\
\text { yang terdaftar pada } \\
\text { Efek Indonesia } \\
\text { secara berturut-turut dari } \\
\text { tahun 2016-2018. }\end{array}$ & 154 \\
\hline 2 & $\begin{array}{l}\text { Laporan } \\
\text { perusahaan manufaktur } \\
\text { tahun 2012-2016 yang } \\
\text { menjelaskan mengenai } \\
\text { tenure audit, ukuran KAP, } \\
\text { ukuran perusahaan dan } \\
\text { kualitas audit. Tidak } \\
\text { lengkap selama tahun 2016- } \\
\text { 2018. }\end{array}$ & 42 \\
\hline 3 & $\begin{array}{l}\text { Nama perusahaan yang } \\
\text { tidak terdaftar pada Bursa } \\
\text { Efek Indonesia(BEI) } \\
\text { 2016-2018 }\end{array}$ & 5 \\
\hline 4 & $\begin{array}{l}\text { perusahaan manufaktur } \\
\text { yang (auditee) mengalami } \\
\text { delisting tahun } 2016-2018\end{array}$ & 1 \\
\hline 5 & $\begin{array}{lr}\text { Keterlambatan } & \text { dalam } \\
\text { Penerbitan } & \text { Laporan } \\
\text { Keuangan pada BEI }\end{array}$ & 2 \\
\hline & Total & 104 \\
\hline
\end{tabular}

Analisis Data

Model Regresi logistic

Model logit statistik yang untuk respon faktor yang berdasarkan satu 
atau lebih memberi pengaruh perubahan bebas lain. Model logit dapat menggunakan cara:

1. Menunjukkan cenderung tetap faktor tidak terikat apabaila faktor terikat tetap dalam cara tertentu.

2. Menjelaskan tersebar antara kurva yang menyatakan suatu ikatan statistik.

Cara logit disebut jenis peluang dimana cara ini responya logit menurut faktor peluang suatu keadaan atau kualitas berfungsi untuk peraturan maupun latar belakang adanya terikat faktor tertentu.

\section{Regresi Logistik Biner}

Cara logit yaitu suatu ulasan sistem informasi yang dipakai buat mengetahui ikatan respon faktor (y) berupa sistem bilangan juga memberi pengaruh buat faktor terikat (x) berkadaan tidak terikat. Outcame pada faktor y sebab terdiri dua jenis yaitu "jadi" dan "batal" yang dinatariskan $\mathrm{y}=1$ (jadi) dan $\mathrm{y}=0$ (batal).

\section{Model Regresi Logistik Biner}

Sistem yang buat faktor tidak terikat (y) berupakategoris atas satu atau bertambah faktor terikat $(\mathrm{x})$ baik yang bersifat kelompok ataupun sinambung. jika faktor y terdiri be atas 2 jenis yaitu "jadi" dan "batal" yang dinatariskan $\mathrm{y}=1$ (jadi) dan $\mathrm{y}=0$ (batal) maka sistem regresi yang bisa diteraapkan yaitu sistem logit. Bagi satu efek fenomena riset, situasi sama 2 kelompok menghasilkan termasuk $\mathrm{Y}$ nilai pengirim.

\section{Menguji Signifikan}

Model Buat tahu memberi pengaruh ataupun tidak standar faktor terikat secara serentak maupun totalitas teori yang dipakai.

$$
\begin{aligned}
& \mathrm{H} 0=\beta 1=\beta 2=\ldots=\beta p=0 \\
& \mathrm{H} 1={ }_{\text {minimal terdapat satu }} \beta \mathrm{k} \neq 0, \mathrm{k}=1,2, \ldots, \mathrm{p}
\end{aligned}
$$

Uji tiap-tiap parameter model (uji W)

Buat tahu memberi pengaruh ataupun tidak standar faktor terikat maka kita perlu melakukan uji teori.

$\mathrm{H} 0: \beta \mathrm{k}=0$ (faktor $\mathrm{X}$ tidak memberi pengaruh faktor $\mathrm{Y}$ )

$\mathrm{H} 1: ß \mathrm{k}=0$ (faktor $\mathrm{X}$ memberi pengaruh faktor Y)

\section{Uji kesesuaian Model}

Model uji kesesuaian model regresi logistik bersetujuan buat melihat apakah model yang didapatkan sudah sesuaiatau belum. Pengujiannya dengan memakai uji Hosmer dan Lemesshow mengguakan hipotesis penguijian memjadi berikut.

H0 : Model sesuai dengan data'

H1: Model tidak sesuai dengan data

\section{HASIL DAN PEMBAHASAN}

\begin{tabular}{|c|c|c|c|c|}
\hline & & $\begin{array}{l}\text { Chi- } \\
\text { square }\end{array}$ & df & Sig. \\
\hline \multirow{3}{*}{$\begin{array}{l}\text { Step } \\
1\end{array}$} & Step & 19,224 & 3 &, 000 \\
\hline & Block & $\overline{19,224}$ & 3 &, 000 \\
\hline & Model & 19,224 & 3 & 000 \\
\hline
\end{tabular}

Tabel 2. Omnibus Tests of Model Coefficients

Sumber: Hasil pengolahan Data (2019)

Pada daftar atas diketahui maka ukuran Chi-squaer sebanyak 19,224 pada degree of freedom yaitu 3 . Mengenai kualitas signifikan 0,000 yang hasilnya makin rendah dari 0,05 , maka bisa disimpulkan seluruhnya jika faktor terikat secara simultan memberi pengaruh atas kualitas audit.

\begin{tabular}{|c|c|c|c|c|c|}
\hline & B & S.E. & Wald & Df & Sig. \\
\hline $\mathrm{x} 1$ & 1,354 &, 376 & 12,967 & 1 &, 000 \\
\hline $\mathrm{S} 1 \mathrm{x} 2$ & ,734 & ,400 & 3,366 & 1 & ,067 \\
\hline $1^{c} \times 3$ & ,037 & ,046 & ,646 & 1 &, 422 \\
\hline Constant & ,028 & 1,314 & , 000 & 1 & ,983 \\
\hline
\end{tabular}

Tabel 3 Variables in the Equation 
Tabel di atas menentukan pengaruh pemeriksaan regresi logit menghasilkan contoh menjadi berikut:

$$
\mathrm{Y}=\mathbf{0 , 0 2 8}+\underset{\mathbf{0 , 0 3 7} \mathrm{X}_{3}}{\mathbf{1 , 3 4 5} \mathrm{X}_{1}+0,734 \mathrm{X}_{2}+}
$$

Bersumber pada persesuaian garis regresi logit terjadi dengan jumlah padakoefesien regresi per faktor terikat, keluasan tingkat interpect maka tingkat koefesien pada faktor terikat bisa interprestasikan. Interprestasi benar buat koefesien akan terkait dalam potensimemuat diri makna defenisi menurut disparitas antara dua cara, kemudian dalam analisis logit, penilaiaan koefesien uraian logit melalui dasar tahu atas istilah odds ratio atau $\operatorname{Exp}(B)$. dariuraian perhitungannya maka hasil regresinya bisapasti jadi selanjutnya.

\section{Pengaruh Audit Tenure Terhadap Kualitas Audit}

Hasil pengujian hipotesis pertama (H1) yang diajukan dalam penelitian ini adalah Audit Tenure berpengaruh positif terhadap Kualitas Audit. Tenure audit merupakan masa perikatan audit antara KAP dan klien terkait jasa audit yang telah disepakati sebelumnya (Panjaitan, 2014). Perusahaan dalam menggunakan jasa dari akuntan publik harus berdasarkan Peraturan Menteri Keuangan Republik Indonesia Nomor 17 / PMK. 01 / 2008 tentang jasa akuntan publik. Perubahan yang terjadi diantaranya adalah pemberian jasa audit umum menjadi 6 tahun buku berturut-turut oleh Kantor Akuntan Publik dan 3 tahun buku berturut-turut oleh Akuntan Publik kepada satu klien yang sama. Hitungan pemeriksaan mengeluarkan uraian buat hipotesis pertama diperoleh bahwa audit tenure menghasilkan nilai koefesien regresi positif sebesar 1,354 dan taraf signifikan 0,000. Dengan demikian hasil penelitiian mendukung teori yang menyajikan atau $\mathrm{H} 1$ diterima.

Menurut hasil penelitian yang dilakukan oleh Nugrahanti \& Darsono, (2014) menunjukkan bahwa hasil penelitian tersebut memberikan bukti empiris bahwa tenure audit berpengaruh terhadap kualitas audit. Pengaruh Reputasi KAP terhadap Kualitas Audit. Ukuran KAP yang besar berpengaruh positif terhadap kualitas audit. Serta pada penelitian Nadia (2015) yang membuktikan spesialisasi auditor berpengaruh positif terhadap kualitas audit. Oleh karena itu dengan adanya besarnya sebuah KAP dan memiliki spesialisasi maka dapat menghasilkan kualitas audit yang lebih baik.

Kualitas audit yang buruk dapat terjadi jika seorang auditor tidak mampu dalam mengungkapkan salah saji material pada laporan keuangan yang dihasilkan. Keterbatasan waktu dalam menelaah perusahaan, menghilangkan bukti-bukti yang disengaja oleh pihak manajemen dapat membuat seorang auditor gagal dalam mengungkapkan salahsaji material tersebut. Sehingga, ketika jika perikatan suatu KAP dengan perusahaan klien terjalin dengan cukup lama, auditor dapat mengetahui bukti-bukti tersebut berdasarkan catatan auditor sebelumnya. Dengan bagitu, buktibukti yang ingin dihilangkan oleh pihak manajemen gagal karena KAP sudah memiliki catatan pada perusahaan klien. Adanya kemampuan seorang auditor mengungkap salahsaji material pada laporan keuangan tersebut dapat meningkatkan pula kualitas audit yang dihasilkan. Semakin lama masa perikatan audit dengan kliennya dapat meningkatkan pengetahuan auditor terhadap perusahaan klien. Namun bertentangan dengan penelitian yang dilakukan oleh Nindita \& Siregar 
(2013). menunjukkan bahwa masa perikatan audit tidak berpengaruh terhadap Kualitas Audit dan beranggapan bahwa perusahaan yang tidak puas dengan kualitas kinerja auditor akan mengakhiri masa perikatan sebelum batas maksimum yang diatur oleh pemerintah. Pilihan yang dibuat perusahaan untuk segera mengakhiri masa perikatan ketika kualitas yang diharapkan tidak diperoleh, hal ini menunjukkan bahwa audit tenure tidak berpengaruh terhadap kualitas audit pada penelitian tersebut.

\section{Pengaruh Ukuran KAP Terhadap Kualitas Audit}

Dari hasil uji statistik t diketahui bahwa variabel Ukuran Kantor Akuntan Publik berpengaruh positif signifikan terhadap Kualitas Audit. Hal ini berarti hasil penelitian menerima hipotesis kedua (H2) bahwa Pengaruh Ukuran KAP Terhadap Kualitas Audit.

Ukuran KAP merupakan ukuran yang digunakan untuk menentukan besar kecilnya suatu Kantor Akuntan Publik (Nabila, 2011). Hal ini dapat dipahami dari banyaknya jumlah permintaan atas jasa Akuntan Publik. Perusahaan besar lebih cenderung memilih KAP besar untuk melakukan jasa audit atas laporan perusahaannya. Ukuran besar kecilnya KAP dibedakan dalam dua kelompok, yaitu KAP yang berafiliasi dengan KAP Big 4 dan KAP yang tidak berafiliasi dengan KAP Big 4. Hitungan pemeriksaan selanjutnya terdapatmaka ukuran berdampak terhadap kualitas audit, lalu teori tadi diperoleh. Melalui nilai regresi logistik memperlihatkan koefesien regresi positif mengunakan jumlah 0,734 menggunakan signifikan sebanyak $0,067<$ berdasarkan 0,05 hal tersebut memperlihatkan maka ukuran kap tidak memberi pengaruh atas kualitas audit. Hasil penelitian ini mengindikasikan bahwa ukuran KAP semakin besar maka semakin tinggi kualitas audit, karena ukuran KAP yang besar telah banyak memiliki pengalaman dalam hal mengaudit semua jenis perusahaan yang ada, hal ini yang dapat meningkatkan kualitas audit.

Hasil penelitian berhasil membuktikan dugaan peneliti mengenai adanya pengaruh positif Ukuran KAP terhadap Kualitas Audit. Temuan penelitian ini mengindikasikan bahwa ketika audit dilakukan oleh KAP besar yang bereputasi tinggi, maka KAP memiliki kemampuan ekonomi dan pengetahuan yang tinggi untuk mencegah tindakan oportunis dan diluar prosedur dari manajemen. KAP besar juga melakukan perekrutan auditor secara ketat sehingga KAP besar dapat menghasilkan auditor terbaik dibanding KAP yang lain sehingga akan meningkatkan kualitas audit

\section{Pengaruh Ukuran Perusahaan Terhadap Kualitas Audit}

Dari hasil uji statistik t diketahui bahwa variabel Ukuran Kantor Akuntan Publik berpengaruh positif signifikan terhadap Kualitas Audit. Hal ini berarti hasil penelitian menerima hipotesis ketiga (H3) bahwa Pengaruh Ukuran Perusahaan Terhadap Kualitas Audit.

Ukuran perusahaan adalah suatu skala yang mengklasifikasikan besar kecilnya perusahaan yang berhubungan dengan financial perusahaan (Nabila, 2011). Ukuran perusahaan dapat dilihat berdasarkan total penjualan, total asset, rata-rata total penjualan, dan rata-rata total asset. Ukuran perusahaan yang diproksikan dengan logaritma natural total asset yang dimiliki menunjukkan kemampuan perusahaan dalam menjaga kelangsungan usaha.Hitung pemeriksaan akhir diperoleh maka ukuran perusahaan berpengaaruh atas kualitas audit, bahwa teori tadi 
diperoleh. Pada nilai regresi logistik menampakan koefesien regresi positif pada jumlah 0,037 mengunakan signifikan sebesar 0,422 >berdasarkan 0,05 faktor memperlihatkan bahwa ukuran perusahaan tidak berpengaruh atas kuliatas audit. Dalam hal ini Ukuran Perusahaan tidak berpengaruh signifikan karena data yang digunakan oleh peneliti adalah data perusahaan yang memiliki total asset yang tinggi sehingga apabila total asset yang tinggi dapat menunjukan bahwa perusahaan tersebut memiliki manajemen yang baik dalam mengelola dan pengendalian intern dan tidak menjadikan ukuran perusahaan salah satu unsur yang berdampak buruk terhadap kualitas audit.

$\begin{array}{rcc}\text { Ukuran } & \text { perusahaan dapat } \\ \text { mempengaruhi } & \text { kualitas }\end{array}$

Perusahaan berukuran besar karena kompleksitas operasi dan peningkatan pemisahan antara manajemen dan pemegang saham, sangat memerlukan KAP yang dapat mengurangi agency cost. Selain itu, jumlah konflik agensi yang meningkat menyebabkan permintaan untuk membedakan kualitas auditor juga meningkat. Oleh karena itu, perusahaan berukuran besar pastinya akan lebih memilih menggunakan jasa KAP berukuran besar untuk menghasilkan laporan audit yang berkualitas. Penelitian yang dilakukan Sinaga (2014) membuktikan bahwa variabel ukuran perusahaan klien berpengaruh secara signifikan terhadap kualitas audit.

\section{PENUTUP \\ Kesimpulan}

Berdasar

pada hasil penelitiannya yang di peroleh menurut hasil uji statistik dan pengkajian yang sudah dijabarkan dalam bab sebelumnya, maka bisa disimpukan seperti di bawah ini.
1. Dari hasil analisis data suatu kesimpulan bahwa hipotesis pertama audit tenure mempengaruhi dengan signifikan terhadap kualitas audit.

2. Dari hasil analisis data suatu kesimpulan bahwa hioptesis kedua ukuran KAP mempengaruhi dengan signifikan terhadap kualitas audit.

3. Dari hasil analisis data suatu kesimpulan bahwa hipotesis ketiga ukuran perusahaan tidak mempengaruhi dengan signifikan terhadap kualitas audit perusahaan manufaktur yang listing pada BEI tahun 2016-2018.

\section{Saran}

Bagi peneliti selanjutnya yang ingin meneliti lebih lanjut diharapkan dapat menambah sampel perusahaan, karena hasil penelitian ini tidak dapat digeneralisasikan ke perusahaan yang lainnya. Bagi peneliti selanjutnya diharapkan dapat menambah variabel independen dalam penelitian dengan harapan hasil penelitian lebih baik dari peneliti ini, missalnya seperti, fee audit, komite audit, dan spesialisasi auditor. Bagi peneliti selanjutnya diharapkan dapat menambahkan priode pengamatan penelitian yang lebih lama lagi, dengan harapan hasil penelitian lebih baik dari penelitian ini.Penulis pula merekomendasikaan saran padapengaudit supaya bisa menaikanpengetahuan dan indepedensinya. Agar menambah kualitas audit dan menjaga reputasinya dimata klien, sebagai akibatnya semakin baik auditor menjaga etika terhadap kualitas audit, sebagai auditor juga harus dapat mengoptimalkan waktu yang disediakan kepada kliennya suupayabisa mencari bukti yang cukup dan kuliatas audit yang didapatkan semakin baik bila auditornya menggunakn waktu tersebut. Semakin baik pengalaman auditor pada suatu 
aktivitas audit maka auditor bisa membentuk kualitas audit yang semakin baik lagi dalam memelihara hubungannyaterhadap kliennya dan sikap memberi keputusan agar tidak bisa dipengaruhipihak manapun.

\section{DAFTAR PUSTAKA}

Nabila. (2011). Faktor-faktor yang Mempengaruhi Auditor Switching.

Nadia, N., F. (2015). Pengaruh Tenur Kap, Reputasi Kap Dan Rotasi Kap Terhadap Kualitas audit. Jurnal Akuntansi Bisnis, 13(26), 113-130.

Nindita, C., \& Siregar, S. V. (2013). Analisis Pengaruh Ukuran Kantor Akuntan Publik Terhadap Kualitas Audit di Indonesia. Jurnal Akuntansi dan Keuangan, 14(2).

Nugrahanti, Y. (2014). Pengaruh Audit Tenure, Spesialisasi Kantor Akuntan Publik dan Ukuran Perusahaan Terhadap Terhadap Kualitas Audit. 678-686.

Nugroho, L. (2018). analisa faktorfaktor yang mempengaruhi kualitas audit (Studi Empiris pada Perusahaan Manufaktur Industri Sektor Barang Konsumsi yang Terdaftar Di Bursa Efek Indonesia tahun 2014-2016). Jurnal Maneksi, 7(1), 55.

Panjaitan, C., M. (2014). Pengaruh Tenure, Ukuran Kap dan Spesialisasi Auditor Terhadap Kualitas Audit, 3(2), 221-232.

Permana, K., X., \& Pamudji, H. S. (2012). Pengaruh Masa Perikatan Audit Dan Ukuran KAP Terhadap Kualitas Audit (Studi Empiris Pada Perusahaan Go Public Yang Terdaftar di BEI Tahun 2010 Kecuali
Perusahaan Jasa Dan Keuangan). 1-27.

Putri, T., M. (2014). Pengaruh Rotasi Kantor Akuntan Publik dan Rotasi Akuntan Publik (Partner Auditor) terhadap Kualitas Audit (Studi Empiris Pada Perusahaan Manufaktur yang Terdaftar di BEI Tahun 2010-2013). 404415.

Sinaga, D., M., T., \& Ghozali, I. (2013). Analisis Pengaruh Audit Tenure, Ukuran KAP dan Ukuran Perusahaan Klien Terhadap Kualitas Audit. Skripsi Universitas Diponegoro, 1(3), $1-27$. 